\title{
Narrative on Nature Conservation: A Comparative Study of the Folktales of Bali Aga and Ainu
}

\author{
*IDA AYU LAKSMITA SARI \\ I NYOMAN DARMA PUTRA \\ Faculty of Arts, University of Udayana, Jalan Nias 13, Bali, Indonesia \\ *Corresponding author: dayumita23@gmail.com
}

Published online: 20 October 2020

To cite this article: Ida Ayu Laksmita Sari and I Nyoman Darma Putra. 2020. Narrative on nature conservation: A comparative study of the folktales of Bali Aga and Ainu. KEMANUSIAAN the Asian Journal of Humanities 27(2): 59-78. https://doi.org/10.21315/kajh2020.27.2.4

To link to this article: https://doi.org/10.21315/kajh2020.27.2.4

\begin{abstract}
The Bali Aga community in northern Bali and the Ainu in northern Japan are indigenous peoples who share in utilising a wealth of folktales as a vehicle for passing down their respective local wisdom across generations. This study comparatively examines Bali Aga and Ainu discourses of local wisdom expressed implicitly and explicitly in these folktales. The focus of the study is to analyse discourses of local wisdom, in particular those relating to nature conservation as reflected in the folktales. The research data were taken from selected Bali Aga and Ainu folktales and analysed through the theoretical lenses of literary anthropology and comparative literature. The analysis shows that in addition to having an aesthetic narrative structure, the Bali Aga and Ainu folktales are also rich in depictions of life skills knowledge, farming methods, livelihoods and cultural values that are useful for fostering public awareness in conserving nature as a resource for cultural maintenance. This article concludes that the folktales of these two ethnic groups offer local wisdom useful for fostering awareness in society of the importance of conserving nature, with the message that despite its abundant resources, nature should not be exploited.
\end{abstract}

Keywords and phrases: folktales, character building, nature conservation, Bali Aga, Ainu

\section{Introduction}

Folktales are a medium for expressing local wisdom in narrative form or through storytelling. Scholars have recognised the cultural value of folktales and have begun documenting these stories for learning materials at schools or reading materials stored in libraries. A half-century ago, Bascom $(1965,239)$ stated that "folktales as pedagogies have been documented in many parts of the world". Likewise, Ainu scholar Brett Walker (2001) underlines the importance of folktales as a medium for maintaining and promoting local wisdom. He states that Ainu folktales express 
many cultural and religious values and model practices when dealing with nature $(2001,111)$. Awareness that folktales can be used as medium for education and to pass on local wisdom across generations indicates the relevance of this oral tradition as it continues to be used from the past and on into the modern era.

In Japan, folktales often provide inspiration for narratives portrayed in anime, which is not only aired on Japanese television stations but also abroad. The beauty of the stories and the dignity of moral values contained within them are some of the reasons why folktales continue to be adopted as part of modern society. Likewise, in Indonesia, the importance of folktales can also be found in several cultural phenomena, including their transformation into performing arts or into common storytelling contests among school children students. Continued interest in printing, performing and studying folktales also highlights the importance of the oral tradition in contemporary life (Pudentia 2015; Magat 2014; Ashkenazi 2008).

The Bali Aga in northern Bali and the Ainu in northern Japan are examples of indigenous peoples fortunate enough to be able to pass on a rich set of folktales, in which there are various moral messages promoting desirable social attributes in community members, in particular those relating to how humans should preserve their natural surroundings. The moral education on the subject of nature in folktales is highly relevant to this study because of the ongoing destruction of nature in various places around the world due to economic necessity and over-exploitation in order to meet human demands. The folktales of both communities contain local wisdom with very strong moral messages, including how humans should treat nature in the sense of making use of it while, at the same time, preserving it. Through folktales, community members are socialised into local wisdom, passed down from generation to generation, which is then used as a model for a way of life and a reference to the collective value system.

This article analyses local wisdom in the folktales of the Bali Aga and the Ainu as a medium of character building, specifically in fostering consciousness around the nurture and conservation of nature as a source of life. It sheds light on how folktales from both communities describe the way traditional societies made use of plants and animals for daily subsistence and how folktales play a role in fostering a community's character with regard to the importance of protecting and preserving nature.

There have been abundant studies on folktales with various focuses and approaches. Ahi, Yaya and Ozsoy (2014), for example, provide an interesting study of the importance of folktales as a medium for education about the environment and culture. The benefits of folktales in this respect are universal, meaning that the 
folktales are available to various ethnicities around the world. Comparative studies of folktales from different countries have provided interesting discussions on the differences and similarities of cultural values and the local wisdom they contain, or the universal values that were created from them. In their study, Ahi, Yaya and Ozsoy (2014) analysed 15 illustrated folktales originating from nine countries, including America, Japan, Africa and Malaysia. Although the folktales' origins vary, their message regarding the environment appears to be similar insofar as they advocate for the need for positive human attitudes and behaviour toward nature as a resource for survival.

In a modern and increasingly globalised era that promotes consumption of material resources, however, orientations and public attention towards local wisdom have not disappeared (Kusumasari and Alam 2012; Jati 2014). The importance of local wisdom is to help solve the problems of daily life and to serve as a resource for realising happiness or a general sense of well-being. Moreover, local wisdom contained in folktales has an entertainment dimension as well, which is a foundation that can foster a sense of joy and happiness in a given community, rather than merely providing solace. Knowing that local wisdom is very important and central to the life of a community, it is not surprising that efforts to preserve and hand down local wisdom from generation to generation are often carried out in earnest. Mediums for preservation and inheritance of local wisdom are oral traditions that include myths, legends and fairy tales which are often called folktales. Folktales are beneficial as a means of inheritance of local wisdom, in legitimising socio-political positions, or just as entertainment for an audience. At the symbolic and cultural level, folktales express the collective consciousness of the local community with regards to their lives, customs and beliefs (Taum 2011, 11).

Local wisdom can be understood as the knowledge and technological system of a community group (Sudikan 2013, 205) or an unwritten form of guidelines, views, rules and policies in society (Marfai, Rahayu and Triyanti 2015, 2). In this article, the discussion of local wisdom through Bali Aga and Ainu folktales is focused on selected stories about the importance of community members to conserve nature as a source of life.

\section{Theoretical Framework and Research Method}

In this study, selected Bali Aga and Ainu folktales are analysed through the theoretical frameworks of literary anthropology and comparative literature. Literary anthropology was first introduced as a term in the title of an essay by Victoria Rippere (1966). Although in the piece she does not elaborate on the meaning and limitations of this approach, in general, she explains what literature 
is and the importance of cultural context in the understanding of literary texts. The anthropological aspects of literature include representations of systems of knowledge, customs, kinship systems, living and technological tools, livelihood, art and belief systems and religion (Sudikan 2007, 6). Myths about the sacredness of forest, land and animals and of spiritual beings that are part of belief systems and religion can still be found in many of the belief systems of ethnic groups in Asia, including those in Indonesia and Japan. In this way, literary anthropology can be used to analyse the local wisdom of Bali Aga and Ainu folktales separately, followed by comparative analysis to better understand the similarities and differences between these cultures' use of folktales.

Comparative literature theory is a principal way of uncovering meanings of literary works from across more than one context. According to Bassnett $(1993,1)$, comparative literature "involves the study of texts across culture, ... it is interdisciplinary and...it is concerned with patterns of connection in literatures across both time and space". The literary texts compared in this study belong to two different ethnic groups.

An example of the application of a cultural approach in comparative analysis of folktales is Ahi, Yaya and Ozsoy (2014), whose study is based on the view that "folktales reflect cultural heritages of cultures, they also reveal viewpoints of the culture they belong to about an issue with their contents. Therefore, it is important to compare and analyse folktales from different cultures".

In their study, the authors conclude that the environment and nature are concepts important to all cultures. Aware of the limitations of the study, they suggest the necessity of further study by including more folktales from more culturally diverse backgrounds. Comparative study based on cultural approaches or literary anthropology not only provide a creative approach to the study of literary texts, but also contribute to anthropology more broadly by considering literary text as "ethnographic source material" (Wiles 2018, 2).

The Bali Aga and the Ainu of Japan have been selected purposefully for analysis using interdisciplinary techniques that combine comparative literary study and anthropological approaches. In addition, it also explores patterns of relationships focused on local wisdom as we have identified in the following examples.

For this study, 10 stories (five each from the Bali Aga and the Ainu) were chosen based on the presence of a theme or subtheme regarding the relationship between humans and nature. The stories of the Bali Aga were taken from more than one source. Four stories were taken from Ceritera Rakyat Bali: Desa Tenganan, 
Pedawa, Tigawasa (Balinese Folktales: Tenganan, Pedawa, Tigawasa Village), a collection by Rata et al. (1987) and published by the Department of Culture, Province of Bali. As its title suggests, this anthology consists of folktales from three different Bali Aga villages. The latter two Bali Aga villages (Pedawa and Tigawasa) mentioned in the title are located in northern Bali. The remaining story is taken from the Gedong Kirtya Library collection in Singaraja in northern Bali as well. All stories in the collection as well as the one from the Kirtya Library are written in the Bali Aga dialect of the Balinese language and accompanied by a summary in Indonesian. The Bali Aga dialect is marked by numerous small differences in vocabulary and slight differences in sentence structure as compared to the Balinese language. The fact that the stories chosen here were published by the governmental body responsible for cultural matters is indicative of the stories' authenticity.

There are 41 stories in this anthology, all having the setting of a local community. Most stories talk about the relationships between humans and gods or other spiritual beings and between humans and other humans and humans and animals. While the former group depicts more serious stories, the latter two are dominated by a sense of humour conveyed by exploiting the foolishness of the characters. Translations in English for the excerpts presented in this analysis are taken from the Balineselanguage text and done by the authors.

Ainu folktales are taken from Ainu no Mukashi Banashi: Hitotsubu no Sacchiporo (Ainu Folktales: A Single Egg of Sacchiporo), an anthology written by Shigeru Kayano (1993), a prominent advocate of Ainu cultural heritage. Kayano was a prolific writer on the subjects of Ainu language and culture, and he even served as the first representative of Ainu descent in the national government where he fought for the political, social and cultural rights of the Ainu community. The anthology contains 21 stories, 20 of which are written in the Japanese language using hiragana (Japanese phonetic script) and one story is written in both Japanese and in the Ainu language using katakana (Japanese phonetic script for words of non-Japanese origin). All of them are set within the value systems of Ainu culture and belief and nature and environment. Ainu folktales are also dominated by stories about the relationship between humans and other humans, humans and kamui (also spelled kamuy; spiritual beings) and humans and nature. The difference between these folktales and those of the Bali Aga is that they are more serious in tone as the stories contain almost no humorous elements. Five folktales were purposefully selected from this book based on the relevance of their theme to the topic under investigation, the importance of harmonious relationships between human beings and nature. Translation into English for discussion and the following analysis were done by the first author. 
The selected stories are analysed separately through the lens of literary anthropology, then compared by looking at similarities and differences between Bali Aga and Ainu folktales using comparative literary approaches. Beyond their entertainment function, the folktales of the two groups analysed below are also loaded with information about life skills, traditional knowledge and important messages regarding nature conservation.

\section{Brief Background of the Bali Aga and Ainu}

The Bali Aga people are the indigenous people who inhabited the island of Bali before the influence of the Majapahit kingdom, a great Hindu kingdom in Java, which ruled most of the Indonesian archipelago until 1400 (Bagus 2004; Reuter 2002; Utama 2015). The word aga means "original" or "mountain". The Bali Aga are often distinguished from "modern Balinese", which generally refers to people who migrated to Bali from Majapahit in Java, often called "wong Majapahit" (the people of Majapahit), who predominantly live in the plains area in the south. Both Bali Aga and "modern Balinese" people are followers of Hinduism. However, the religion of the Bali Aga is more strongly influenced by "ancient Balinese" traditions that predate the arrival of Hinduism to the island (Simpen 1986).

The Bali Aga people generally live in mountainous areas spread across eastern Bali and northern Bali. The Bali Aga is an ethnic minority but have a distinctive, strong and rich cultural tradition that is exemplified in their folktales, architecture and ritual tradition (Simpen 1986; Utama 2015). The villages of the Bali Aga in northern Bali have cultural and natural potentials that have recently been developed as tourist attractions (Andini and Pujaastawa 2018). It is estimated that around 300 visitors participate in this ethnic tourism every week. Visitors can see the daily life of old Bali, the traditional housing with typical characteristic and various types of handicraft made from bamboo, one of the plants native to the area. The central, provincial and local governments have promoted Bali Aga villages in northern Bali for village tourism by providing, among other things, financial support to preserve traditional housing and to build infrastructure. These villages are located about 35 minutes from the Lovina beach area where there are many hotels and villas. For visitors who stay in the Lovina beach area, the Bali Aga villages have become popular tourist attractions.

The Ainu are an indigenous people who mainly live in northern Japan, primarily on the island of Hokkaidō. The word ainu means "human" in the Ainu language. They are thought to be descendants of the people who entered the Japanese archipelago before the Jōmon era (prehistoric times), occupying a large area among the islands located across what is now Russia and Japan. When the Japanese colonised the 
island of Hokkaido in the 18th century the Ainu and their lands were forced to become part of Japan and their identity as a distinct ethnic group was erased as the Ainu were compelled to assimilate into Japanese culture. For decades the Ainu were considered a "dying race" (Neary 2012, 294), beginning in 1899 when the Japanese government issued a law recognising the Ainu people simply as "former natives" (Cheung 2003, 952). The Ainu have struggled long to be acknowledged as an indigenous people of Japan and their campaign to gain this recognition received global support when the United Nations declared the 1990s to be the "Decade of the World's Indigenous People". On 6th June 2008, the Japanese parliament accepted a resolution that "recognised the Ainu as one of the indigenous peoples of Japan" (Low 2012, S66; Watson, Lewallen and Hudson 2014, 1), but for many Ainu this is still not enough, as the resolution offered no legal protections.

In their development, both the Bali Aga and Ainu communities have maintained their identity as indigenous peoples, while still being minority communities. Although most indigenous peoples in different countries or regions are often both a minority and socially marginalised, they have cultural power which manifests in their local wisdom that is preserved as the foundation of their identity (Reuter 1999, 167). In different contexts and levels of intensity, the Bali Aga and Ainu have become marginalised in their own regions. Both geographically and economically they may be disadvantaged, but culturally, the Bali Aga maintain strong traditions and culture as the basis of their identity and with appropriate institutional supports to counteract more than a century of forced assimilation policies, the Ainu could leverage these same cultural assets toward maintaining their ethnic identity as well.

Both groups uphold their traditions and culture, including folktales. Recently, in November 2018, the Bali Aga community in northern Bali planted a local type of rice ( gaga) after having abandoned it for almost half a century in favour of a crop that matures more quickly. They have returned to the traditional crop because of the belief that the community should use gaga rice to offer to their gods. This is a good example of not only how a community can regain their commitment to tradition, but also to offer thanks to god with an authentic type of offering. The planting of gaga rice took place with a special celebration where local journalists and government officers were invited to witness the revived tradition. As with the Bali Aga, some Ainu have shown interest in developing their community as a tourist attraction. The uniqueness of Ainu cultural heritage and tradition is a major attraction for Japanese society and international tourists (Hiwasaki 2000, 395-412). While domestic tourism to Ainu communities increases (Nikkei Asian Review 2017), Japanese are gradually taking greater interest in traditional Ainu practices and rituals. However, because of ongoing disputes over land ownership between the Ainu people and the national government, these practices and rituals 
are often limited in the community's ability to carry them out, especially in regard to the more well-known yet no longer practiced iomante (discussed as follows), highlighting the crucial role nature plays in Ainu life. As time goes by, Ainu people continue to develop and promote their culture as best they can and thus their identity as well. Incidentally, Ainu festivals have begun to be performed in the Tokyo metropolitan area, further indicating the commitment of Ainu people to maintaining and promoting their culture openly and with a sense of pride.

A comparative examination of the folktales of these two ethnic groups contributes to our understanding of the role of their local wisdom in preserving nature and environment, a subject of a high universal importance. Although this article is based on a limited number of stories from two different ethnic groups, further study of folktales from these two communities, as well as those from other ethnic groups across around the world, would help to overcome any limitations of the present study.

\section{Messages of Nature Conservation in Bali Aga and Ainu Folktales}

The importance of maintaining harmony between human and natural environments is very prominent in the stories selected for this study. From an anthropological point of view, the people of Bali Aga and the Ainu share similar cultural values. This can be seen in their systems of belief in God (for Bali Aga) or kamui (for Ainu). The Bali Aga community, like most followers of Balinese Hinduism, believe in only one god, but one that is omnipresent everywhere with different names and functions, manifesting as, for example, a god of the sea, a god of the mountains and gods that reside in large trees. The belief in an omnipresent God in Bali Aga society can be seen in religious or customary practices. People in Tigawasa Village, refer to forests as duwe, a Balinese word which means "inheritance from God", something which is "sacred" (Wijana 2013, 226), a "holy place" that must be guarded as protected (ibid., 290). Preservation of this holy place is done through the practice of religious ceremonies which are meant to please the spiritual beings they believe to reside there and in return they ask for their protection. In this context, deforestation is believed to expose the community into intangible risk and is always avoided. Local wisdom like this has contributed to the conservation of Bali Aga forest in northern Bali, compared to increasing deforestation in other parts of Bali (Wijana 2013; 2014). Many Bali Aga folktales reflect this belief system which is discussed further in the following section.

Similarly, the Ainu people believe that everything in the physical world-mountains, trees, lakes and animals - are inhabited by spirits and therefore they must be treated with respect (Walker 2001). The most well- 
known Ainu ceremony, iomante (in which a bear cub is captured and raised by a community for a short time before being ritually sacrificed), returns a bear's spirit to the spirit world and is "the most precious of all ritual performances practiced by the Ainu" (Sjöberg 2013, 52). The Ainu's belief in the omnipresence of spiritual beings is reflected in their folktales making it possible to say that their folktales are inseparable from a social belief system. Since their folktales are set within the environmental contexts of Ainu society, much of the local wisdom contained within relates to the important relationship between humans and gods and humans and nature.

\section{The Bali Aga ways of taking care of natural resources}

The five Bali Aga folktales analysed clearly narrate the life skills of the Bali Aga people as they pertain to nature. The stories are very typical of Balinese folktales in that they employ the name of the character in the title of the story and the moral messages, including those of the conservation of nature, are delivered through the characters and their practices, either explicitly or implicitly. The message of forming good characteristics in the people of the community is firmly embedded in the stories (as shown in Table 1).

Table 1. List of Bali Aga folktales with nature conservation related themes

\begin{tabular}{|c|c|c|c|}
\hline Number & $\begin{array}{l}\text { Title (name of the } \\
\text { character) }\end{array}$ & Life skills & $\begin{array}{c}\text { Character building } \\
\text { message }\end{array}$ \\
\hline \multirow[t]{2}{*}{1} & I Calang (I Calang) & Catching shrimp & $\begin{array}{l}\text { Catching shrimp with } \\
\text { poison should be avoided. }\end{array}$ \\
\hline & & $\begin{array}{l}\text { Curing stomach aches with } \\
\text { drink made of herbs (loloh) } \\
\text { and medicine made of } \\
\text { chewed herbs (simbuh) }\end{array}$ & $\begin{array}{l}\text { People can cure illness } \\
\text { with herbal ingredients. }\end{array}$ \\
\hline 2 & $\begin{array}{l}\text { I Gesah ring Ni Gesih } \\
\text { (I Gesah and } \mathrm{Ni} \\
\text { Gesih) }\end{array}$ & $\begin{array}{l}\text { Catching fish with traps made } \\
\text { of woven bamboo }(b u b u)\end{array}$ & $\begin{array}{l}\text { Using traditional tools is a } \\
\text { natural way to catch fish. }\end{array}$ \\
\hline 3 & $\begin{array}{l}\text { Pan Bangsing teken I } \\
\text { Belog (Pan Bangsing } \\
\text { and I Belog) }\end{array}$ & $\begin{array}{l}\text { Catching eel with traps made } \\
\text { of woven bamboo }(b u b u)\end{array}$ & $\begin{array}{l}\text { Using traditional ways } \\
\text { to catch eel is a way of } \\
\text { avoiding exploitation of } \\
\text { the environment. }\end{array}$ \\
\hline 4 & I Tumpit (I Tumpit) & $\begin{array}{l}\text { Strategic conservation of } \\
\text { forest area }\end{array}$ & $\begin{array}{l}\text { Excessive logging has } \\
\text { negative impacts. }\end{array}$ \\
\hline 5 & Sinayu (Sinayu) & $\begin{array}{l}\text { Technique of cooking a type } \\
\text { of insect (sinayu) }\end{array}$ & Sinayu is a source of food. \\
\hline
\end{tabular}


I Calang is a tragic folktale, which tells the story of the main character, I Calang, who dies of illness from eating shrimp caught with tuba (poison). The life skill of catching shrimp with tuba is illustrated at the beginning of the story:

Kacarita teked di Lebahe, nyakcak lahutnya ya, ba keto pasangina men tuba tibune to. Tibune to madan tibu Sasape. Disubane ba ya masangang tuba di tibune, bin japennyene liyu danget udange teka, ngebekin tibune to, sampe nda ho bena nuduk. Ya ngaba wadah tabis dadua bek ba to makadadua. Udange ngaliyuneng duang tekanyene.

[...] Kacarita be ya ngamah, sakit te basang I Calange, jrat-jrit nyakitang basang, gaenang loloh tekang somahnyene, simbuna pada, masih nda nyak ilang sakitnyane.

(Rata et al. 1987, 94)

Translation:

It is said that when he arrived at a river, he (I Calang) made a poison and threw it out into the river. The area was named Sasape River. After he threw the poison into the water, a few moments later a lot of shrimp came, so much that he could not collect them all. He took only two containers, both filled with shrimp. The number of shrimp continued to grow.

[...] It is said that after he ate the shrimp, I Calang got a stomach ache, he screamed in pain, then his wife made loloh and she spat on him using an herbal simbuh as part of the treatment, but still, his pain did not disappear.

I Calang obtained an abundance of shrimp, but the two containers he prepared were not able to accommodate the large catch. The way I Calang caught the shrimp is through using poison, which he deliberately spread in the river. The poison was made of root of a particular tree after it has been dried. The roots are then ground and mixed with water. Then, it is spread on the edge of the river (Alamendah 2010). The intoxicated shrimp are then very easily captured. Although tuba is a natural poison and formerly a lot of fishermen used it, it can also endanger human life if too great an amount is used. This is illustrated when I Calang dies after eating the shrimp he caught using an excessive amount of tuba.

This story is interesting because it conveys a layered and inverse message. First, it is not justified at all to catch shrimp with poison because it will kill shrimp and other creatures in the river. Second, shrimp caught with tuba contain toxins, can cause stomach ache if consumed, possibly resulting in death. Third, to cure the stomach ache caused by tuba, one can drink loloh (drink made of herbs) and use simbuh (traditional medication). The narration about the use of loloh and simbuh 
teaches about the use of herbs for medicinal treatment. The death of I Calang underscores the importance of the message that people must be careful when consuming poisoned shrimp.

The story I Gesah ring Ni Gesih similarly takes its title from the names of its main characters and both stories deal with catching shrimp. Unlike in the story I Calang, however, I Gesah ring Ni Gesih offers a natural method without poison or causing unintentional death. The character I Gesah catches shrimp with two $b u b u$, traps made from woven bamboo. Bait is put in the back hole of the bubu and they are placed in river or creek, usually in the early evening, with the hope shrimp or fish will enter the bubu to consume the bait overnight and they are retrieved in the morning. The following quote expresses how I Gesah set the $b u b u$, checked them the following day and is happy as he found a lot of shrimp:

Pasangange lantas bubune totonen. Bin maninene delokina lantas bubune tekeneng I Gesah, makadadua bubune bak misi udang. Adepa lantas udange totonen tekeneng adinene. Maan ya ngadep udang, anggona nguup tekeneng I Gesah. Ngelemeng ya sapala-sapala maan udang, payu lantas ya medaar ulihan ngadep-adep udang.

(Rata et al. 1987, 140)

Translation:

The $b u b u$ were set. The next day I Gesah saw the bubu, his two bubu filled with shrimp. Then the shrimp were sold by his sister. The result is that I Gesah was able to go shopping. Every day, they always caught shrimp so that they could provide food for themselves from selling the shrimp.

This story also contains elements of a magical being (a powerful, unseen person) who helps I Gesah and Ni Gesih by first giving them a magical horse which can produce gold from its excrement and then a magical stone which produces whatever I Gesah and Ni Gesih ask it to make. Character building using local wisdom in this story occurs within the good nature of I Gesah and Ni Gesih. From the beginning of the story until the end, both characters behave well, work hard and respect others as well as the gods, which constitutes a moral lesson for readers.

A similar theme of connecting people's lives with nature occurs in the story Pan Bangsing teken I Belog (Pan Bangsing and I Belog). Apart from telling a story about how people catch eels for food using bubu, the story contains a message about moral behaviour as well. One of the main characters, I Belog (belog in Balinese means "stupid"), acts foolishly with the other main character, Pan Bangsing. When 
I Belog sets the $b u b u$, Pan Bangsing follows him so that he knew where the traps were. The following morning, I Belog finds his bubu empty because all the eel had been removed earlier. Pan Bangsing tricks I Belog several times until God comes to punish Pan Bangsing for his bad behaviour, turning him from rich to poor and causing him to suffer. By contrast, I Belog, who had always been unlucky in his life but behaved well, receives help from God to live prosperously. While on the one hand this story tells about the close relationship between humans and nature as a source of subsistence, on the other it expresses what constitutes good moral behaviour.

Cutting down forests and destroying the balance of an ecosystem is the theme of the story I Tumpit. The story is from Pedawa (a Bali Aga village in northern Bali) and tells of a monkey which comes every day to I Tumpit's house to ask for food. The monkey always eats yams boiled for I Tumpit's father and mother, so much so that their family is eventually starving. I Tumpit's father gets angry and threatens the monkey, telling it to not come back to his house. In the story, it is said that the monkey comes to I Tumpit's house and takes their food because the forest where the monkeys live has been logged by humans, destroying their habitat. Deforestation therefore deprives the monkeys of food. The monkey admits his mistake, by saying:

Aduh-aduh Pan Tumpit aku pelih pesan basaja ngamah amahan mene, aku seduk krana di alase uba tora ada apa, alase abase, kayu kayune baha nang jelemane.

(as told by I Wayan Sukrata, pers. comm., 8 April 2017)

Translation:

Oh Pan-Tumpit, I admit that I am very guilty for eating this food, I am hungry because there is nothing in the forest, the forest is cut down, the wood is cut by the humans.

In Bali, monkeys are considered holy animals and they are protected. Along with the monkeys, the forest is considered a holy place to be protected. The moral message is layered within the story, first establishing that massive logging destroys the ecosystem and the animals that used to live in the now barren forestland have lost their habitat and sources of food. Following this, it depicts how destruction of animal habitats creates new problems for humans. The effects of disturbances on human life are thus due to the negative actions of humans towards nature. Through I Tumpit, Bali Aga society in particular indirectly urges people to stop cutting down forests carelessly. 
The importance of conservation of the environment is also reflected in the story Sinayu, an insect used by Bali Aga as a culinary dish. Although the insect can be found almost everywhere in Bali, it is unusual to cook them. The story not only tells of how to catch and cook sinayu, but also how to ensure the conservation of the tree where the sinayu grow and live. In short, it expresses a message regarding the importance of environmental conservation as it is a source of human food.

Three observations can be made from the five Bali Aga stories. First, the five stories illustrate that nature is a source of community life, where people get food and other necessities. Second, the stories portray nature as a source of life which, if over-exploited, could threaten human life. Third, nature should be preserved not only in order to reach sustainability but also to ensure the balance of ecosystems humans rely on for food and other necessities. In some stories, the existence of spiritual beings or magical powers are included as literary devices to strengthen the message of the importance of the natural protection and hence conservation through a connection with spirituality.

\section{The Ainu ways of taking care of natural resources}

The five Ainu stories analysed also demonstrate how humans are highly dependent on nature. In this regard, conservation efforts are the main theme. The Ainu's unique belief system is reflected in their folktales, for example the concept of kamui that considers plants and animals to be gods (Walker 2001, 52). Messages about the need for nature conservation and caring for resources as a source of life are communicated in the five Ainu folktales selected in this analysis (as shown in Table 2).

Table 2. List of Ainu folktales with nature conservation related themes

\begin{tabular}{cllll}
\hline Number & \multicolumn{1}{c}{ Title } & \multicolumn{1}{c}{ Life skills } & \multicolumn{2}{c}{$\begin{array}{c}\text { Character building } \\
\text { message }\end{array}$} \\
\hline 1 & $\begin{array}{l}\text { Hitotsubu no } \\
\text { Sacchiporo } \\
\text { (A Single Egg of } \\
\text { Sacchiporo) }\end{array}$ & $\begin{array}{l}\text { Processing food for all } \\
\text { seasons; Techniques of } \\
\text { consuming salmon eggs } \\
\text { (sacchiporo })\end{array}$ & $\begin{array}{l}\text { 1. Food should not be } \\
\text { wasted. }\end{array}$ \\
& $\begin{array}{l}\text { Food can be preserved. } \\
\text { Tachiki to Totta Sumou } \\
\text { (Fighting Sumo Against } \\
\text { Strong Tree) }\end{array}$ & $\begin{array}{l}\text { Nature should not be } \\
\text { exploited, } \\
\text { compumption of deer and } \\
\text { bear meat and preserved } \\
\text { dried leaves }\end{array}$ & $\begin{array}{l}\text { Food materials should } \\
\text { be preserved for later } \\
\text { consumption. }\end{array}$ \\
\hline
\end{tabular}


Table 2. (continued)

\begin{tabular}{|c|c|c|c|}
\hline Number & Title & Life skills & $\begin{array}{c}\text { Character building } \\
\text { message }\end{array}$ \\
\hline 3 & $\begin{array}{l}\text { Iedeshita Inu } \\
\text { (The Dog That Left } \\
\text { Home) }\end{array}$ & $\begin{array}{l}\text { Hunting with the help } \\
\text { of dogs }\end{array}$ & Humans must love pets. \\
\hline 4 & $\begin{array}{l}\text { Pukusa no Tamashii } \\
\text { (The Soul of Pukusa } \\
\text { Plant) }\end{array}$ & $\begin{array}{l}\text { Picking leaves for food } \\
\text { material }\end{array}$ & $\begin{array}{l}\text { 1. Leaves should not be } \\
\text { over-picked. } \\
\text { 2. Seeds should be saved } \\
\text { for the next season. }\end{array}$ \\
\hline 5 & $\begin{array}{l}\text { Fune ni natta Ki no } \\
\text { Kamui } \\
\text { (God of Trees } \\
\text { Transformed into } \\
\text { Boats) }\end{array}$ & Making wooden boats & $\begin{array}{l}\text { Cutting down a tree must } \\
\text { be preceded by prayer as a } \\
\text { way of properly respecting } \\
\text { nature. }\end{array}$ \\
\hline
\end{tabular}

Hitotsubu no Sacchiporo is about a girl living with her elderly parents. The girl, without any specified name, is depicted getting food materials from the forest, processing and cooking them so that they can be consumed directly or stored to be consumed during different seasons. The life skill of women gathering and processing foodstuffs is directly related to the cycle of seasons during which, for example, certain plants are not available and must be preserved for continued consumption. The story not only emphasises how nature provides people with foodstuffs, but also the skills Ainu people use to prepare their food. The following excerpt explains how the main character gathers food materials and how she cooks them.

I did the work that women can do, in spring I picked wild plants that we can eat, or during winter, drying and preserving the plants, providing for my elderly parents.

When summer came, I washed the ubayuri root I dug up clean with water and crushed it finely, taking the starch to eat. The leftover starch is wrapped in green grass and fermented. The fermented food was made into large dango with a diameter of 15 centimetres and dried and was made into a foodstuff for the long winter. When the cold winter comes and we eat dango, we soften it using water, process it in a mortar and once more make and boil the dango to eat.

...then I saw a house. Outside the house, there is plenty of dried meat and fish that look good to eat. 
In this excerpt, we learn how the girl survives by processing forest products and wrapping them in grass leaves. In the spring, she plucks wild plants that can be used as sources of food as much as possible because the plants will also be fermented and preserved in order to be used as a source of food during the winter. The northernmost island of Hokkaidō has the coldest temperatures in Japan, making it impossible to find food outdoors in winter. In summer, the female characters in the story look for ingredients to make dango cakes to be preserved for consumption in winter. The story also describes how the Ainu process animals obtained by hunting. The girl comes to the house of a man whose marriage to her has been arranged by her parents, where she sees meat and fish that have been preserved by hanging on the roof, suggesting that the Ainu have long known how to manage natural sources of food. This way the same wild plants or other food can be processed and eaten throughout all four seasons. Similarly, the animals they catch are preserved so that no food is wasted.

Preservation of foodstuffs is an important life skill among the Ainu as represented in their folktales. A similar theme is also depicted in the story Tachiki to Totta Sumou. Told from the point of view of a girl in a small family, the story expresses how the girl's parents get food from nature and how they preserve it so the food can be consumed over a longer period of time. The girl talks about how her parents hunt and collect food materials from nature.

My father caught a lot of deer and bears, my mother harvested wild vegetables in different seasons and dried them and I was given wild vegetables boiled with dried meat or dried fish to eat. (Kayano 1993, 129)

In addition to suggesting a gendered division of labour, with the father going hunting and the mother picking wild vegetables, the narrative of this story likewise depicts the Ainu way of life in terms of food preservation by drying meat, fish and vegetables. The practice of processing food to last the season is how Ainu culture adapts to the demands of nature and this serves as a cultural aspect of their folklore in accordance with literary anthropology.

Ainu stories also express a close interdependence of humans with plants. The community is expected to respect plants not only as source of food but also as a manifestation of kamui, one example being Pukusa no Tamashii. It describes how spirits of kamui live in plants and those who do not respect them will face serious risk, including sickness. The following quote shows how a character from the story suffers from picking the pukusa plant to excess. 
The illness of the village chief's wife was caused by her not knowing how to collect wild plants for preservation. All the grasses and trees that grow in the mountains have a spirit, a function and are sent from Heaven, but when the village chief's wife picked the wild plants, especially the pukusa, she completely uprooted them, not leaving even a single stalk. If you pull it up from the smallest root, next spring it cannot sprout because the spirit of the pukusa will die.

The owner of this house is a good man, but because his wife eradicated all of the pukusa, the god of the pukusa got angry and made the woman sick to make her aware of her mistake.

(Kayano 1993, 88)

In this story, it becomes known that the wife of the village chief is dying because she does not know how to gather plants and has picked them excessively. The Ainu people believe that every living being has a soul and from among the plants she picked there was a plant called pukusa (a kind of leek) that she has taken all of, so much so that the spirit of the pukusa died and could not grow the next spring. This story teaches the community to utilise their natural resources in a way that does not include over-picking them. This message is an indirect articulation of moral values where people are expected to preserve nature and the environment.

The Ainu not only have a great respect for plants as in the story of Pukusa no Tamashii, but also for animals, like bears and dogs. The story Iedeshita Inu tells of a dog that is the descendant of the Bear God, the most important deity in the belief system of the Ainu (Walker 2001). It describes a small dog that was forgotten by his owner, who now has new pets, three big dogs. The reader learns that the little dog is beaten by the owner, tormented by the bigger dogs and the small dog's food is even eaten by other dogs. After the dog leaves his owner's house he meets his real family, which turns out to be one of the gods of the Ainu. Here the story clearly shows that this dog is kamui. After learning his origins and meeting his mate, he returns to the home of his original owner when he was a puppy, now as a full-grown dog, to take care of the person who had kept him then. The moral message conveyed in this story is one of debt repayment.

The story Fune ni Natta Ki no Kamui also teaches how to conserve nature by giving examples that are not appropriate to imitate. In this story, the villagers cut down large trees and the felled timber is to be used to make a boat for transporting merchandise. While the previous stories use the theme of nature as source of food, in this story, it is more strongly emphasised that nature is an important source for making equipment, in this case boats for transportation. It describes how humans 
cut down katsura trees without prayer and consequently the god who had been enthroned in the tree became angry. But when another man wants to cut down a tree, he prays first and the tree offers itself to be cut down and expresses its willingness to be made into a big boat. This story suggests that negative actions taken by humans towards nature, in this case, trees will cause the humans problems if these actions are done without reverence, implying that if humans do not respect trees, the trees will react similarly. Trees in Ainu folklore are not just ordinary plants, but plants protected by gods and even trees themselves are gods.

\section{Comparison of Narratives of Conservation between Bali Aga and Ainu Folktales}

From the analysis of the Bali Aga and Ainu folktales, it can be seen how both ethnic groups' folktales pay special attention to the importance of human conservation of nature. Nature is represented as a source of human life that can be utilised but should not be exploited blindly because negative behaviour towards nature can be a source of misfortune for humans. The story of I Calang, in which the title character catches shrimp with poison, is a metaphor with a very clear message that states those who exploit nature will die. A similar message is also found in the Ainu story Pukusa no Tamashii, a story which results in humans suffering from pain due to the curse of the pukusa kamui. In contrast, as reflected in the Bali Aga story I Gesah ring Ni Gesih and the Ainu story Hitotsubu no Sacchiporo, folktales can teach ways to make use of natural resources in a sustainable manner without taking advantage of them to excess.

Comparatively, the following three points can be noted in relation to the goal of increasing awareness around character building among community members with regard to fostering harmonious relationships between human beings and nature. First, the folktales of the Bali Aga and the Ainu contain the moral that nature is a source of human life that should not be exploited if humans want to avoid misfortune. Second, when conveying messages on the importance of nature conservation, the Bali Aga and Ainu folktales deploy narrative devices in the form of a tragic scene, where people can die or be cursed by gods when exploiting nature. With such tragic devices, the story's message can be firmly conveyed people should not exploit but rather conserve nature. And finally, stories from both ethnic groups teach ways to use nature with the principle of sustainability by using traditional knowledge and upholding the community's belief system, that nature and its contents are sacred or divine (kamui) in the Ainu understanding, which must be respected and upheld. 
In the Balinese context, the harmonious relationship between humans and God, humans and other humans, and humans and the environment is referred to as Tri Hita Karana (three sources of prosperity). This Balinese Hindu philosophical concept is reflected in Bali Aga and Ainu folktales. Although the philosophical concept of Tri Hita Karana is not part of Ainu culture, their stories contain many values similar to the teachings of Tri Hita Karana. This can be seen in some Bali Aga and Ainu stories that present discourses concerning the relationship between humans and gods or kamui (Ainu gods), while many stories depict relations between humans and other humans and between humans and nature. The nature of the relationships is that they are either in harmony or disharmony. Although there are Bali Aga and Ainu folktales that depict disharmony and are dominated by conflicts or tragedy, they are examples of behaviours that are not worthy to follow. Their messages are clear on the need of the people to respect nature as a way of conserving it.

\section{Conclusion}

This article discusses how folktales of Bali Aga and Ainu in Japan share similar themes and interests in promoting the importance of awareness toward the conservation of nature and the environment. As can be seen in the analysis, folktales of these two ethnic groups offer local wisdom that is useful for fostering awareness in society around the importance of conserving nature, with the message that, despite its abundant resources, nature should not be exploited. The messages regarding the importance of conserving environmental resources were expressed in both direct and indirect ways, such as when death is used as a punishment for those who have exploited nature in a morally undesirable way. This form of punishment is shared by Bali Aga and Ainu folktales as can be read respectively in I Calang and Pukusa no Tamashii, where both of the main characters of the story die as a result of their actions. The recurrent themes and subthemes of local wisdom that relate to the dependence of human beings on nature are expressed in both Bali Aga and Ainu folktales, indicating that these two ethnic groups share similar values regarding the importance of maintaining a harmonious relationship between human beings and nature.

\section{Acknowledgements}

Part of this research was supported by funding of Penelitian Disertasi Doktor (PDD) and the program of Peningkatan Kualitas Publikasi Internasional (PKPI) 2018 supported by the Ministry of Research, Technology and Higher Education, Republic of Indonesia. We gratefully acknowledge the support. 


\section{References}

Ahi, B., Yaya, D. and Ozsoy, S. 2014. The concept of environment in folktales from different cultures: Analysis of content and visuals. International Electronic Journal of Environment Education 4(1): 1-17. https://doi.org/10.18497/iejee-green.64123

Alamendah. 2010. Tuba, tumbuhan peracun ikan dan serangga. Retrieved from https:// alamendah.org/2010/01/12/tuba-tumbuhan-peracun-ikan-dan-serangga/ (accessed 13 May 2017).

Andini, N.D. and Pujaastawa, I.B.G. 2018. Peran serta elit desa dalam pengembangan pariwisata di Desa Cempaga Kecamatan Banjar Kabupaten Buleleng Bali. Jurnal Humanis 22(1): 87-95. https://doi.org/10.24843/JH.2018.v22.i01.p13

Ashkenazi, M. 2008. Handbook of Japanese mythology. New York: Oxford University Press.

Bagus, I.G.N. 2004. Kebudayaan Bali. In Manusia dan kebudayaan di Indonesia, ed. Koentjarningrat, 286-306. Jakarta: Djambatan.

Bascom, W. 1965. The forms of folklore: Prose narratives. The Journal of American Folklore 78(307): 3-20. https://doi.org/10.2307/538099

Bassnett, S. 1993. Comparative literature: A critical introduction. Cambridge: Blackwell.

Cheung, S.C.H. 2003. Ainu culture in transition. Futures 35: 951-959. https://doi. org/10.1016/S0016-3287(03)00051-X

Hiwasaki, L. 2000. Ethnic tourism in Hokkaido and the shaping of Ainu identity. Pacific Affairs 73(3): 393-412. https://doi.org/10.2307/2672026

Jati, I.RA.P. 2014. Local wisdom behind tumpeng as an icon of Indonesian traditional cuisine. Nutrition and Food Science 44(4): 324-334. https://doi.org/10.1108/NFS11-2013-0141

Kayano, S. 1993. Ainu mukashi banashi: Hitotsubu no sacchiporo. Tokyo: Heibonsha.

Kusumasari, B. and Alam, Q. 2012. Local wisdom-based disaster recovery model in Indonesia. Disaster Prevention and Management 21(3): 351-369. https://doi. org/10.1108/09653561211234525

Low, M. 2012. Physical anthropology in Japan: The Ainu and the search for the origins of the Japanese. Current Anthropology 53(5): 557-566. https://doi. org/10.1086/662334

Magat, M.C. 2014. In search of Southeast Asian folklorists. Western Folktales 73(2/3): 280-296.

Marfai, M.A., Rahayu, E. and Triyanti, A. 2015. Peran kearifan lokal dan modal sosial dalam pengurangan risiko bencana dan pembangunan pesisir: Integrasi kajian lingkungan, kebencanaan, dan sosial budaya. Yogyakarta, Indonesia: Gadjah Mada University Press.

Neary, I. 2012. Sarah Mehlhop Strong. Ainu spirits singing: The living world of Chiri Yukie's Ainu shin'yoshu. Asian Ethnology 71(2): 294-295.

Nikkei Asian Review. 2017. Hokkaido highlights its indigenous heritage as a tourism asset, 24 August. Retrieved from https://asia.nikkei.com/NAR/Articles/Hokkaidohighlights-its-indigenous-heritage-as-a-tourism-asset (accessed 14 June 2018).

Pudentia, M.P.S.S., ed. 2015. Metodologi kajian tradisi lisan. Jakarta: Asosiasi Tradisi Lisan. 
Rata, I.B. et al. 1987. Ceritera rakyat Bali: Desa Tenganan, Pedawa, Tigawasa. Denpasar, Indonesia: Dinas Kebudayaan Provinsi Bali.

Reuter, T. 2002. Custodians of the sacred mountains: Culture and society in the highlands of Bali. Honolulu: University of Hawai'i Press.

. 1999. People of the mountain, people of the sea: Negotiating the local and the foreign in Bali. In Staying local in the global village: Bali in the twentieth century, eds. R. Rubinstein and L. Connor, 155-180. Honolulu: University of Hawai'i Press. https://doi.org/10.1515/9780824864460-009

Rippere, V.L. 1966. Towards an anthropology of literature. Structuralism 36/37: 243-251. https://doi.org/10.2307/2930408

Simpen, W.A.B. 1986. Adat kuna catur desa: Tigawasa, Sidatapa, Pedawa, Cempaga. Unpublished research report, Universitas Udayana.

Sjöberg, K.V. 2013. The return of the Ainu: Cultural mobilization and the practice of ethnicity in Japan. London: Routledge. https://doi.org/10.4324/9781315077130

Sudikan, S.Y. 2013. Kearifan lokal dalam tradisi lisan Nusantara: Penggalian nilai-nilai kebhinekaan untuk Indonesia masa kini dan masa depan. In Foklor Nusantara: Hakikat, bentuk, dan fungsi, ed. S. Endraswara, 200-228. Yogyakarta, Indonesia: Ombak. 2007. Antropologi sastra. Surabaya, Indonesia: Unesa University Press.

Taum, Y.Y. 2011. Studi sastra lisan: Sejarah, teori, metode dan pendekatannya disertai contoh penerapannya. Yogyakarta: Lamalera.

Utama, I.W.B. 2015. Wajah Bali tanpa kasta: Pudarnya identitas Bali Aga. Bali: Pustaka Ekspresi.

Walker, B.L. 2001. The conquest of Ainu lands: Ecology and culture in Japanese expansion, 1590-1800. Berkeley: University of California Press.

Watson, M.K., Lewallen, A. and Hudson, M.J. 2014. Beyond Ainu studies: An introduction. In Beyond Ainu studies: Changing academic and public perspectives, eds. M.J. Hudson, A. Lewallen and M.K. Watson, 1-24. Honolulu: University of Hawai'i Press. https://doi.org/10.21313/hawaii/9780824836979.003.0001

Wijana, N. 2013. Pengelolaan hutan berbasis kearifan lokal di Desa Tigawasa, Kecamatan Banjar, Kabupaten Buleleng. Prosiding seminar nasional FMIPA UNDIKSHA III tahun 2013, 226-232. Bali, Indonesia: Fakultas Matematika dan Ilmu Pengetahuan Alam Universitas (FMIPA), Universitas Pendidikan Ganesha (UNDIKSHA).

. 2014. Analisis komposisi dan keanekaragaman spesies tumbuhan di hutan Desa Bali Aga Tigawasa, Buleleng-Bali. Jurnal Sains dan Teknologi 3(1): 288-299. https://doi.org/10.23887/jst-undiksha.v3i1.2907

Wiles, E. 2018. Three branches of literary anthropology: Sources, styles, subject matter. Ethnography 21(2): 280-295. https://doi.org/10.1177/1466138118762958 